\title{
Monipuolisen väkirehun merkitys ja valkuaisruokinnan optimointi maito- rotuisten sonnien ruokinnassa eri ikäkausina
}

\author{
Arto Huuskonen ${ }^{1)}$ ja Eveliina Turpeinen ${ }^{2)}$ \\ ${ }^{1)}$ Maa- ja elintarviketalouden tutkimuskeskus, Kotieläintuotannon tutkimus, Tutkimusasemantie 15, \\ 92400 Ruukki, arto.huuskonen@mtt.fi \\ ${ }^{2)}$ Helsingin yliopisto, Maataloustieteiden laitos, Kotieläintiede ja Kotieläinbiotekniikka, PL 28, 00014 \\ Helsingin yliopisto, eveliina.turpeinen@helsinki.fi
}

\section{Tiivistelmä}

Tutkimuksen tavoitteena oli selvittää maitorotuisten sonnien saaman valkuaislisän ja monipuolisen väkirehun merkitystä. Päätavoitteena oli tutkia ja optimoida koko kasvatuskauden valkuaisruokintaa ja selvittää vaikuttaako monipuolinen väkirehu tuotantotuloksiin verrattuna yksinkertaiseen ohraruokintaan, kun karkearehuna käytetään hyvälaatuista nurmisäilörehua.

Koko koe muodostui kahdesta erillisestä osakokeesta. Ensimmäinen kasvatuskoe alkoi marraskuussa 2007 ja loppui toukokuussa 2009. Kasvatuskoe toistettiin tammikuun 2009 ja heinäkuun 2010 välisenä aikana. Yhteensä kokeessa oli 60 maitorotuista sonnia, jotka kasvatettiin viiden eläimen ryhmäkarsinoissa. Eläimet tulivat kokeeseen ternivasikoina keskimäärin kahden viikon iässä ja ne arvottiin kokeen alussa kolmelle erilaiselle koeruokinnalle: 1) väkirehuna litistetty ohra (O-ryhmä), 2) väkirehuna litistetty ohra + rypsirouhe (OR-ryhmä) ja 3) väkirehuna teollinen täysrehu (TR-ryhmä) (Primo -sarja). Eläimet olivat samoilla koeruokinnoilla kahden viikon iästä teurastukseen saakka. Juottokaudella (vasikoiden ikä 2 vk-2,5 kk) vasikat saivat vapaasti väkirehua, nurmisäilörehua, kuivaa heinää ja vettä. Juomarehua oli tarjolla rajoitetusti maksimiannoksen ollessa 8,5/eläin/vrk. Juoton jälkeisellä teinikaudella (ikä 2,5-6 kk) eläimet saivat vapaasti nurmisäilörehua, kuivaa heinää ja vettä mutta väkirehun maksimiannos oli rajoitettu (3 kg/eläin/vrk). Loppukasvatuskaudella (ikä 6-18 kk) sonnit ruokittiin vapaasti seosrehulla. Seosrehun väkirehuprosentti oli 50 kaikilla väkirehuruokinnoilla. Rypsilisän keskimääräinen annostelumäärä oli kokeen aikana keskimäärin $0,5 \mathrm{~kg} / \mathrm{eläin} / \mathrm{vrk}$.

Säilörehun kemiallinen ja ravitsemuksellinen koostumus sekä käymislaatu olivat molemmissa kokeissa hyviä samoin kuin säilörehun sulavuus (D-arvot 675 ja $695 \mathrm{~g} / \mathrm{kg} \mathrm{ka}$ ). Juottokaudella eläinten kasvu, rehun syönti tai ravintoaineiden saanti ei eronnut ruokintaryhmien välillä toisistaan, koska jokaisessa ryhmässä pääasiallinen ravinnonlähde oli juomarehu. Teinikaudella päiväkasvu oli litistettyä ohraa saaneilla vasikoilla selvästi matalampi kuin ohraa + rypsiä tai teollista täysrehua saaneilla vasikoilla. Sonnit hyötyivät rypsin ja teollisen täysrehun ohraa korkeammasta valkuaispitoisuudesta, kun taas ohra-ruokinnalla valkuaisen saanti rehusta ei riittänyt parhaan kasvutuloksen saavuttamiseen. Puolen vuoden iässä OR- ja TR-ryhmien sonnien painot eivät eronneet toisistaan (241 vs. $242 \mathrm{~kg}$ ), mutta O-ryhmän sonnit olivat $26 \mathrm{~kg}$ kevyempiä. Ero kuitenkin kompensoitui loppukasvatuskauden aikana ja loppupainoissa 18 kuukauden iässä ei ollut enää eroa ruokintaryhmien välillä. Loppukasvatuskaudella eikä koko koeajalle lasketuissa kasvu-, syönti tai teurastuloksissa ollut eroja väkirehuruokintaryhmien välillä.

Lisävalkuaisruokinnasta ei koko kasvatuskautta ajatellen ole etua naudanlihantuotannossa, jos sonnit kasvatetaan välitysvasikoista teurasikään samalla tilalla. Valkuaislisän alkukasvatuskaudella saatu lisäkasvu kompensoituu loppukasvatuskauden aikana eikä valkuaislisään sijoitettu panos tuota taloudellista etua. Täysrehulla ei saavutettu etuja viljaväkirehuun nähden. Täysrehun ohraa suurempi valkuaispitoisuus paransi kasvuja alkukasvatuskaudella samoin kuin rypsilisä, mutta tämäkin ero kompensoitui loppukasvatuskauden aikana.

Asiasanat: naudanlihantuotanto, sonnit, ruokinta, valkuainen, väkirehut 


\section{Johdanto}

Tutkimuksen tavoitteisiin kuului selvittää maitorotuisten sonnien saaman valkuaislisän ja monipuolisen väkirehun biologista ja taloudellista merkitystä tarkastellen koko kasvatuskautta. Päätavoitteina oli tutkia ja optimoida koko kasvatuskauden valkuaisruokintaa ja selvittää onko monipuolisella väkirehulla vaikutusta tuotantotuloksiin verrattuna yksinkertaiseen ohraruokintaan, kun karkearehuna käytetään hyvälaatuista nurmisäilörehua. Hypoteesina oli, että valkuaislisä parantaa alkukasvatuskaudella vasikoiden kasvua, mutta ero kompensoituu loppukasvatuskaudella. Samoin oletettiin, että monipuolinen, maittava ja ohraa valkuais- ja kuitupitoisempi väkirehu parantaa vasikoiden rehun syöntiä ja kasvua alkukasvatuskaudella ohraruokintaan verrattuna. Tutkimuksessa haluttiinkin tutkia, miten alkukasvatuskaudella mahdollisesti syntyvät erot muuttuvat loppukasvatuskauden aikana ja miten väkirehun koostumus vaikuttaa sonnien teurastuloksiin.

\section{Aineisto ja menetelmät}

Koe suoritettiin MTT:n Siikajoen toimipisteessä. Koko koe muodostui kahdesta erillisestä osakokeesta. Ensimmäinen kasvatuskoe alkoi marraskuussa 2007 ja loppui toukokuussa 2009. Kasvatuskoe toistettiin tammikuun 2009 ja heinäkuun 2010 välisenä aikana. Sekä ensimmäisessä että toisessa kasvatuskokeessa sonneja oli 30. Ensimmäisessä kokeessa 18 eläintä oli rodultaan ayrshirejä (ay) ja 12 holstein-friisiläisiä (fr). Toisessa kokeessa ayrshirejä oli 19 ja holstein-friisiläisiä 11. Eläimet ryhmiteltiin heti tulopäivänä satunnaisesti kuuteen viiden sonnin ryhmään kolmelle erilaiselle koeruokinnalle siten, että kullekin ruokinnalle tuli mahdollisimman sama määrä ay- ja fr-rodun elämiä. Yhtä koeruokintaa kohti oli kaksi karsinaa kummassakin osakokeessa. Näillä ruokinnoilla eläimet olivat kokeen loppuun saakka. Alkukasvatuskaudella, alle puolivuotiaina, eläimet olivat navetassa viiden vasikan ryhmäkarsinoissa, joiden koko oli 3,0 × 3,5 m. Tilaa yhtä vasikkaa kohti oli 2,1 $\mathrm{m}^{2}$. Eläimet siirrettiin kuuden kuukauden iässä neljä viikkoa kestävälle parsijaksolle, jotta ruokintojen sulavuus voitiin määrittää. Loppukasvatuskaudeksi eläimet siirrettiin kylmäpihattoon viiden eläimen ryhmäkarsinoihin samoissa ryhmissä, joissa ne olivat olleet vasikkakaudella. Pihatossa karsinan koko oli 4 × $8 \mathrm{~m}$. Yhtä eläintä kohti tilaa oli $6,4 \mathrm{~m}$, josta makuualuetta $3,2 \mathrm{~m}$ /eläin. Ruokintapöydällä tilaa oli $80 \mathrm{~cm} / \mathrm{eläin}$. Juontipaikkoja oli yksi 10 eläintä kohti.

Alkukasvatuskausi jakaantui kahteen osaan, ternikasvatuskauteen (eläinten ikä 2,5 vk-2,5 kk) ja teinikasvatuskauteen (eläinten 2,5 kk - $6 \mathrm{kk}$ ). Koko alkukasvatuskauden ajan rehut tarjottiin erillisruokintana. Väkirehujen ja säilörehun lisäksi tarjolla oli heinää kaikille ruokintaryhmille. Ternikasvatuskaudella kaikki vasikat saivat päivässä 8,5 litraa kaupallista juomarehua (Startti Auto, Valio Oy). Juottokaudella vasikoille oli tarjolla vapaasti väkirehua ja säilörehua koeruokintansa mukaan. Alkukasvatuskauden aikana kokeessa oli kolme erilaista väkirehukoekäsittelyä: 1) ohra + kivennäinen (Oruokinta), 2) seos, jossa $80 \%$ ohraa ja $20 \%$ rypsitiivistettä + kivennäinen (OR-ruokinta) ja 3) teollinen täysrehu (Primo I, Suomen Rehu Oy) (TR-ruokinta).

Juotolta vieroituksen jälkeen eläimet saivat vapaasti nurmisäilörehua. Väkirehun määrä rajoitettiin maksimissaan $3 \mathrm{~kg} / \mathrm{pv} / \mathrm{eläin}$ kuuden kuukauden ikään saakka. Vasikat saivat ns. lääkerehuna myös heinää, mikäli niillä ilmeni ripulia. Kuuden kuukauden iästä alkaen sonnit saivat vapaasti seosrehua, jossa säilörehu-väkirehu suhde oli 1/1 kuiva-aineesta. Rypsilisällä pyrittiin siihen, että OR- ja TRruokintojen raakavalkuaispitoisuudet olisivat keskenään yhdenmukaiset. Kuuden kuukauden iästä eteenpäin teurastukseen asti seosrehukoeruokinnat olivat seuraavat: 1) kuiva-aineesta $50 \%$ nurmisäilörehua ja $50 \%$ litistettyä ohraa (O-ruokinta), 2) kuiva-aineesta $50 \%$ nurmisäilörehua ja $50 \%$ litistettyä ohraa + rypsitiivistettä $500 \mathrm{~g} /$ eläin / päivä (OR-ruokinta) ja 3) kuiva-aineesta 50 \% nurmisäilörehua ja $50 \%$ teollista täysrehua (TR-ruokinta).

Seoksiin käytettiin tutkimustilalla tuotettua ohraa sekä kaupallista täysrehua (Primo-sarja, Suomen Rehu Oy). Täysrehussa kivennäiset ja vitamiinit olivat valmiina, mutta ohraseosrehua saaneiden sonnien riittävästä vitamiinin ja kivennäisten saannista piti huolehtia erikseen. Sonnit saivat kivennäislisää alkukasvatuskaudella (Mulli-Melli, Raisio Oy) ja loppukasvatuskaudella (Kasvu-apekivennäinen, A-Rehu Oy) ja vitamiinitäydennysrehua koko kasvatuskauden ajan (Xylitol ADEsan, Suomen Rehu Oy). Rehujen koostumustiedot on esitetty yksityiskohtaisesti Huuskosen (2011) julkaisussa.

Rehujen kemiallinen koostumus määritettiin Huuskosen (2009) kuvailemalla tavalla. Säilörehusta määritettiin lisäksi käymislaatu (pH, kokonaistyppi, liukoinen typpi, ammoniumtyppi, haihtuvat rasvahapot ja maito- sekä muurahaishappo) puristenestetitraukseen pohjautuvalla laatumäärityksellä ja D-arvo määritettiin NIR-menetelmällä. Rehujen energia- ja valkuaisarvot laskettiin MTT:n (2010) 
kuvaamalla tavalla. Sonnien päiväkasvu laskettiin loppupainon ja kokeen alun painon erotuksena jaettuna kasvatuspäivillä. Nettokasvu laskettiin teuraspainon ja kokeen alun ruhopainon erotuksena jaettuna kasvatuspäivillä. Ruhopainona kokeen alussa käytettiin elopaino $\times 0,4$. Teurasruhot luokiteltiin EUROP - luokituksen mukaisesti. Koejärjestelyt ja tutkimusmenetelmät on esitetty yksityiskohtaisemmin Huuskosen (2011) julkaisussa.

Tilastollisen testauksen koemalli oli täysin satunnaistettu koe, jossa havaintoyksikkönä oli karsina. Tällöin karsinakohtainen havainto koostui viiden eläimen keskiarvosta. Rehujen syönnin osalta jokaisesta karsinasta voitiin mitata tämä yksi karsinakohtainen havainto. Eläinten kasvu- ja teurastulosten osalta käytössä oli jokaiselta eläimeltä mitattu tulos, jotka sitten yhdistettiin karsinakohtaiseksi havainnoksi. Sulavuuskokeen ajan eläimet olivat parteen kytkettyinä, joten sulavuuskokeen tuloksissa havaintoyksikkönä on käytetty yksittäistä eläintä. Tulosten tilastollisena käsittelynä tehtiin varianssianalyysi SAS-ohjelmiston GLM-proseduurilla. Testauksessa käytetty koemalli oli $y_{\mathrm{ijk}}=\mu+\alpha_{\mathrm{i}}+\beta_{\mathrm{j}}+$ $(\alpha \times \beta)_{\mathrm{ij}}+\mathrm{e}_{\mathrm{ijk}}$, missä $\mu$ on yleiskeskiarvo, $\alpha_{\mathrm{i}}$ on koekäsittelyn vaikutus (i=1,2,3), $\beta_{\mathrm{j}}$ on kokeen vaikutus $(\mathrm{j}=1,2),(\alpha \times \beta)_{\mathrm{ij}}$ on käsittelyn ja kokeen yhdysvaikutus $\mathrm{ja} \mathrm{e}_{\mathrm{ijk}}$ on virhetermi. Koekäsittelyjen väliset tilastolliset erot testattiin kahdella ortogonaalisella kontrastilla: $\mathrm{C} 1=\mathrm{O}$ vs. OR ja $\mathrm{C} 2=\mathrm{O}$ vs. TR. Tuloksia esitettäessä taulukoissa on ilmoitettu koekäsittelyn, kokeen ja koekäsittelyn ja kokeen yhdysvaikutuksen merkitsevyystaso ( $p$-arvo).

\section{Tulokset ja tulosten tarkastelu \\ Rehujen koostumus ja ruokintojen sulavuus}

Kokeessa käytettyjen rehujen koostumukset ja rehuarvot on esitetty taulukossa 1. Säilörehun säilönnällinen laatu oli kokeen aikana hyvä käymishappojen pitoisuuden sekä ammonium- ja liukoisen typen osuuksien perusteella mitattuna. Säilörehun sulavuus oli molemmissa kokeissa hyvä (D-arvot 675 ja $695 \mathrm{~g} / \mathrm{kg} \mathrm{ka})$.

Ruokintojen sulavuudet on esitetty näennäisinä in vivo - sulavuuksina (Taulukko 2). Täysrehuruokinnalla kuiva-aineen, orgaanisen aineen ja NDF:n sulavuudet olivat heikompia kuin Oruokinnalla. Kyseinen ero johtui todennäköisimmin eri rehukomponenttien välisistä sulavuuseroista, sillä rehutaulukoiden (MTT 2010) perusteella ohran orgaanisen aineen ja kuidun sulavuudet ovat parempia kuin tämän tutkimuksen täysrehun komponentteina käytettyjen kauran, mäskijauhon, kaurankuorijauhon tai vehnäleseen vastaavat sulavuudet. Lisäksi väkirehun NDF-pitoisuuden lisääntyessä suhteessa säilörehun NDF-pitoisuuteen, NDF:n sulavuus huononee, koska säilörehun kuitu on sulavampaa kuin väkirehun kuitu (Taulukko 1).

O- ja OR-ruokintojen välillä ei ollut eroa kuiva-aineen, orgaanisen aineen ja NDF:n sulavuuksissa. Raakavalkuaisen sulavuus oli kuitenkin OR-ruokinnalla parempi kuin O-ruokinnalla. Myös Huhtanen ym. (1989) raportoivat raakavalkuaisen sulavuuden parantuneen valkuaislisää tarjottaessa. Tuolloin kuitenkin todettiin, että typpeä erittyi virtsaan enemmän annettaessa lisävalkuaista. Minsonin (1982) mukaan valkuaisen sulavuuden parantuminen onkin suurimmaksi osaksi näennäistä. Tämä johtuu sontaan erittyvän endogeenisen typen osuuden vähenemisestä sonnan typessä ruokinnan valkuaispitoisuuden lisääntyessä.

\section{Syönti ja ravintoaineiden saanti}

Ternikasvatuskaudella syönnit eri ruokinnoilla eivät eronneet toisistaan eikä energian tai ravintoaineiden saannissa ollut eroja koekäsittelyjen välillä (Taulukko 3), koska jokaisessa ruokintaryhmässä pääasiallinen ravinnonlähde oli juomarehu.

Teinikasvatuskaudella vasikoiden kuiva-aineen syönti oli suurempi OR- ja TR-ruokinnoilla kuin O-ruokinnalla. Tästä johtuen vasikat saivat OR- ja TR-ruokinnoilla enemmän muuntokelpoista energiaa kuin ohraruokinnalla. O-ruokinnalla sonnit saivat vähemmän raakavalkuaista kuin OR-ruokinnalla tai TR-ruokinnalla. Kokonaisuudessaan raakavalkuaisen saanti jäi 204-247 g vähäisemmäksi Oruokinnalla verrattuna muihin ruokintoihin. Ohutsuolessa imeytyvän valkuaisen pitoisuus oli suhteessa raakavalkuaisen saantiin eri ruokinnoilla.

Kokeessa toteutuneet ruokinnan väkirehutasot loppukasvatuskaudella olivat O-, OR- ja TRseoksilla 520, 519 ja $496 \mathrm{~g} / \mathrm{kg}$ ka. Energian saanti ei loppukasvatuskaudella eronnut ryhmien välillä (Taulukko 3). OR-ruokinnalla sonnit saivat 7,4 \% ja O-ruokinnalla $14 \%$ vähemmän raakavalkuaista kuin TR-ruokinnalla. PVT erosi merkitsevästi ruokintojen välillä siten, että O-ruokinnalla PVT oli 160, OR-ruokinnalla -94 ja TR-ruokinnalla $221 \mathrm{~g} / \mathrm{vrk}$. 
Taulukko 1. Kokeessa käytettyjen rehujen kemialliset koostumukset ja rehuarvot.

\begin{tabular}{|c|c|c|c|c|c|c|c|c|}
\hline & $\begin{array}{l}\text { Säilörehu, } \\
\text { koe 1 }\end{array}$ & $\begin{array}{l}\text { Säilörehu, } \\
\text { koe } 2\end{array}$ & Heinä & Juomarehu & Ohra & Rypsirouhe & $\begin{array}{l}\text { Täysrehu (juotto- ja teini- } \\
\text { kasvatuskausi) }\end{array}$ & $\begin{array}{l}\text { Täysrehu (loppu- } \\
\text { kasvatus) }\end{array}$ \\
\hline Näytteitä, kpl & 14 & 14 & 12 & 4 & 14 & 14 & 6 & 10 \\
\hline Kuiva-ainetta (ka), g/kg rehua & 324 & 260 & 888 & 965 & 874 & 881 & 875 & 870 \\
\hline Orgaaninen aine, $\mathrm{g} / \mathrm{kg} \mathrm{ka}$ & 922 & 936 & 947 & 919 & 971 & 914 & 927 & 926 \\
\hline Raakavalkuainen, g/kg ka & 173 & 161 & 62 & 206 & 124 & 351 & 185 & 145 \\
\hline $\mathrm{NDF}, \mathrm{g} / \mathrm{kg} \mathrm{ka}$ & 536 & 550 & 685 & 16 & 204 & 318 & 242 & 306 \\
\hline Sulamaton NDF, g/kg ka & 60 & 51 & $\mathrm{ND}^{\mathrm{a}}$ & 2 & 43 & 133 & 46 & 91 \\
\hline Raakarasva, g/kg ka & 39 & 43 & 21 & 170 & 22 & 40 & 53 & 47 \\
\hline Tärkkelys, g/kg ka & 12 & 7 & ND & 48 & 525 & 22 & 327 & 360 \\
\hline D-arvo, g/kg ka & 675 & 695 & 550 & - & - & - & - & - \\
\hline Muuntokelpoinen energia, MJ/kg ka & 10,8 & 11,1 & 8,8 & 19,9 & 13,1 & 11,7 & 12,4 & 11,9 \\
\hline $\mathrm{OIV}, \mathrm{g} / \mathrm{kg} \mathrm{ka}$ & 85 & 86 & 74 & 180 & 104 & 151 & 111 & 102 \\
\hline PVT, g/kg ka & 27 & 14 & -63 & - & -38 & 111 & 29 & 3 \\
\hline \multicolumn{9}{|l|}{ Säilörehun säilönnällinen laatu } \\
\hline $\mathrm{pH}$ & 4,3 & 4,0 & & & & & & \\
\hline Haihtuvat rasvahapot, g/kg ka & 6 & 18 & & & & & & \\
\hline Maito- ja muurahaishappo, $\mathrm{g} / \mathrm{kg} \mathrm{ka}$ & 35 & 53 & & & & & & \\
\hline Sokeri, g/kg ka & 87 & 46 & & & & & & \\
\hline \multicolumn{9}{|l|}{ Kokonaistypestä, g/kg } \\
\hline Ammoniumtyppi & 49 & 56 & & & & & & \\
\hline Liukoinen typpi & 459 & 504 & & & & & & \\
\hline
\end{tabular}

${ }^{\mathrm{a}} \mathrm{ND}=$ ei määritetty.

Taulukko 2. Väkirehun koostumuksen ja valkuaislisän vaikutukset ruokinnan sulavuuteen.

\begin{tabular}{|c|c|c|c|c|c|c|c|c|c|}
\hline & \multicolumn{3}{|c|}{ Väkirehu $^{a}$} & \multirow[b]{2}{*}{ SEM $^{\mathrm{b}}$} & \multicolumn{5}{|c|}{ Tilastollinen merkitsevyys $^{c}$} \\
\hline & $\mathrm{O}$ & OR & TR & & $\mathrm{R}$ & $\mathrm{K}$ & $\mathrm{R} \times \mathrm{K}$ & $\mathrm{C} 1$ & $\mathrm{C} 2$ \\
\hline \multicolumn{10}{|l|}{ Sulavuuskertoimet } \\
\hline Kuiva-aine & 0,775 & 0,779 & 0,725 & 0,0038 & $* * *$ & $* * *$ & $* *$ & & $* * *$ \\
\hline Orgaaninen aine & 0,786 & 0,794 & 0,740 & 0,0038 & $* * *$ & $* * *$ & $* * *$ & & $* * *$ \\
\hline Raakavalkuainen & 0,722 & 0,799 & 0,708 & 0,0043 & $* * *$ & $* * *$ & $* *$ & $*$ & \\
\hline Neutraalidetergenttikuitu & 0,679 & 0,686 & 0,608 & 0,0069 & $* * *$ & $* * *$ & & & $*$ \\
\hline
\end{tabular}

${ }^{\mathrm{a}} \mathrm{O}=$ väkirehuna litistetty ohra; $\mathrm{OR}=$ väkirehuna litistetty ohra + rypsi; TR = väkirehuna teollinen täysrehu.

${ }^{\mathrm{b}}$ Keskiarvon keskivirhe.

${ }^{\mathrm{c}} \mathrm{R}=$ Ruokintakäsittely, $\mathrm{K}=\mathrm{Koe}, \mathrm{R} \times \mathrm{K}=$ Ruokintakäsittelyn ja kokeen yhdysvaikutus. Ruokintojen väliset erot testattiin ortogonaalisilla kontrasteilla: $\mathrm{C} 1$ = $\mathrm{O}$ vs. OR ja $\mathrm{C} 2$

$=\mathrm{O}$ vs. TR. $* * *(\mathrm{p}<0,001), * *(\mathrm{p}<0,01), *(\mathrm{p}<0,05)$ ja o $(\mathrm{p}<0,10)$. 
Taulukko 3. Väkirehun koostumuksen ja valkuaislisän vaikutukset sonnien rehun syöntiin ternikaudella (0,5-2,5 kk:n iässä), ternikaudella (2,5-6,0 kk:n iässä) ja loppukasvatuskaudella $(6,0-18,0 \mathrm{kk}: \mathrm{n}$ iässä)

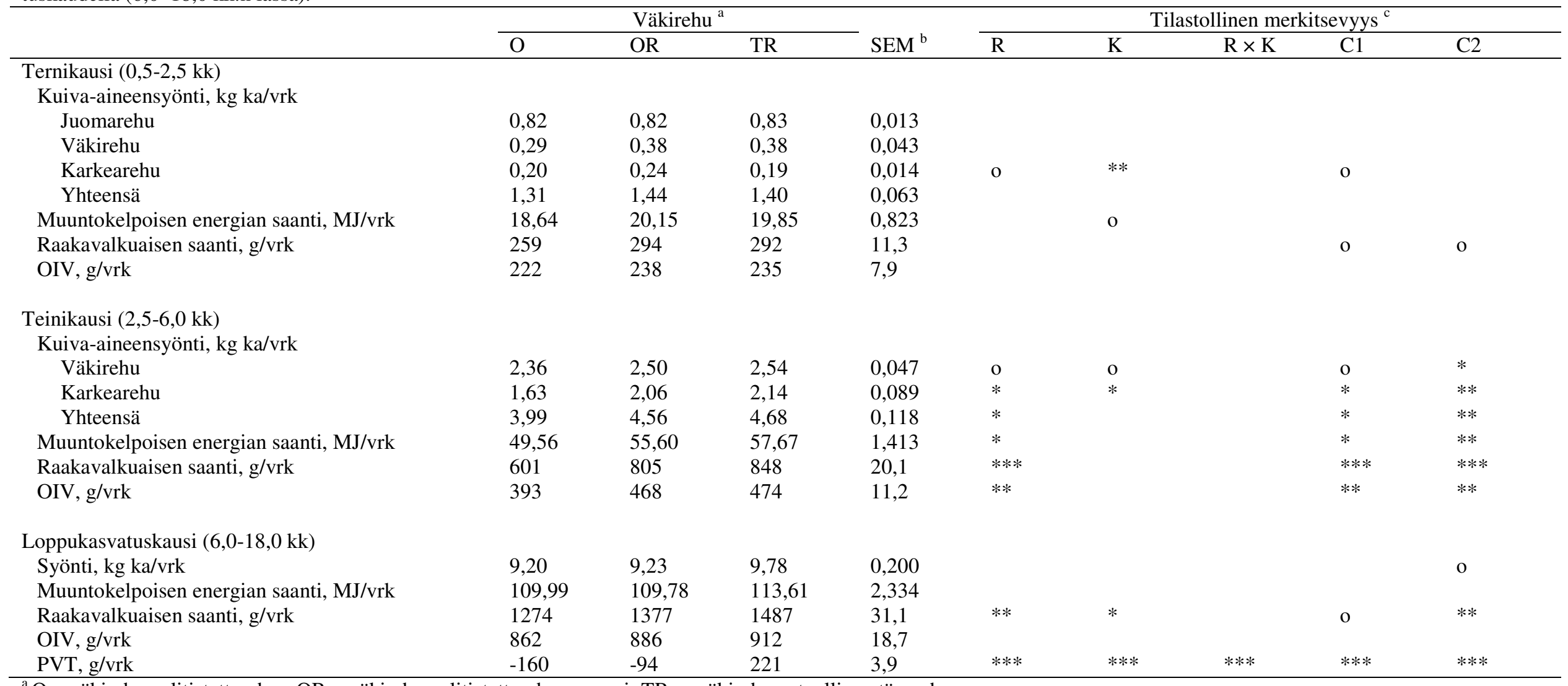

${ }^{a} \mathrm{O}=$ väkirehuna litistetty ohra; OR = väkirehuna litistetty ohra + rypsi; TR = väkirehuna teollinen täysrehu.

${ }^{\mathrm{b}}$ Keskiarvon keskivirhe.

${ }^{\mathrm{c}} \mathrm{R}=$ Ruokintakäsittely, $\mathrm{K}=\mathrm{Koe}, \mathrm{R} \times \mathrm{K}=$ Ruokintakäsittelyn ja kokeen yhdysvaikutus. Ruokintojen väliset erot testattiin ortogonaalisilla kontrasteilla: $\mathrm{C} 1$ = $\mathrm{O}$ vs. OR ja C2 $=\mathrm{O}$ vs. TR. $* * *(\mathrm{p}<0,001), * *(\mathrm{p}<0,01), *(\mathrm{p}<0,05)$ ja o $(\mathrm{p}<0,10)$. 
Taulukko 4. Väkirehun koostumuksen ja valkuaislisän vaikutukset sonnien elopainoon, päiväkasvuun ja rehun hyväksikäyttöön ternikaudella (0,5-2,5 kk:n iässä), ternikaudella (2,5-6,0 kk:n iässä) ja loppukasvatuskaudella (6,0-18,0 kk:n iässä) sekä keskimäärin kokeen aikana. Väkirehun koostumuksen ja valkuaislisän vaikutukset teurastuloksiin.

\begin{tabular}{|c|c|c|c|c|c|c|c|c|c|}
\hline & \multicolumn{3}{|c|}{ Väkirehu $^{\mathrm{a}}$} & \multirow[b]{2}{*}{ SEM $^{\mathrm{b}}$} & \multicolumn{5}{|c|}{ Tilastollinen merkitsevyys $^{c}$} \\
\hline & $\mathrm{O}$ & OR & TR & & $\mathrm{R}$ & $\mathrm{K}$ & $\mathrm{R} \times \mathrm{K}$ & $\mathrm{C} 1$ & $\mathrm{C} 2$ \\
\hline \multicolumn{10}{|l|}{ Elopaino, kg } \\
\hline alussa, 0,5 kk:n iässä & 50 & 55 & 55 & 1,2 & $*$ & & & $*$ & $*$ \\
\hline ternikauden lopussa, 2,5 kk: iässä & 86 & 94 & 92 & 2,7 & & & & o & \\
\hline teinikauden lopussa, 6 kk:n iässä & 216 & 241 & 242 & 3,8 & $* *$ & & & $* *$ & $* *$ \\
\hline 12 kk:n iässä & 428 & 441 & 451 & 6,1 & o & $*$ & & & $*$ \\
\hline lopussa, 18 kk:n iässä & 650 & 660 & 673 & 9,2 & & & & & \\
\hline \multicolumn{10}{|l|}{ Päiväkasvu, g/vrk } \\
\hline ternikaudella & 653 & 717 & 686 & 45,1 & & & & & \\
\hline teinikaudella & 1198 & 1355 & 1384 & 32,4 & $*$ & & & $*$ & $* *$ \\
\hline loppukasvatuskaudella & 1142 & 1116 & 1126 & 20,66 & & & & & \\
\hline keskimäärin kokeen aikana & 1105 & 1115 & 1138 & 17,7 & & & & & \\
\hline \multicolumn{10}{|l|}{ Rehun hyväksikäyttö } \\
\hline \multicolumn{10}{|l|}{ MJ / päiväkasvu-kg } \\
\hline ternikaudella & 30,45 & 30,40 & 30,24 & 1,430 & & & & & \\
\hline teinikaudella & 41,96 & 41,57 & 41,99 & 1,064 & & $*$ & & & \\
\hline loppukasvatuskaudella & 96,51 & 99,71 & 101,21 & 2,341 & & & & & \\
\hline keskimäärin kokeen aikana & 80,39 & 81,33 & 81,81 & 1,323 & & & & & \\
\hline \multicolumn{10}{|l|}{ Teurastulokset } \\
\hline nettokasvu, g/vrk & 585 & 595 & 609 & 12,9 & & & & & \\
\hline teuraspaino, $\mathrm{kg}$ & 338 & 345 & 351 & 6,8 & & & & & \\
\hline teurasprosentti, $\mathrm{g} / \mathrm{kg}$ & 520 & 523 & 524 & 3,8 & & $*$ & & & \\
\hline lihakkuus, EUROP-luokitus ${ }^{\mathrm{d}}$ & 4,75 & 4,43 & 4,85 & 0,267 & & & & & \\
\hline rasvaisuus, EUROP-luokitus ${ }^{\mathrm{e}}$ & 2,65 & 2,47 & 2,52 & 0,150 & & o & & & \\
\hline \multicolumn{10}{|c|}{ Rehun hyväksikäyttö keskimäärin kokeen aikana } \\
\hline $\mathrm{Kg} \mathrm{ka} /$ nettokasvu-kg & 12,59 & 12,69 & 13,02 & 0,263 & & & & & \\
\hline MJ / nettokasvu-kg & 151,67 & 152,55 & 153,00 & 3,372 & & & & & \\
\hline g raakavalkuaista / nettokasvu-kg & 1772 & 1956 & 2035 & 43,0 & $*$ & $\mathrm{o}$ & & $*$ & $* *$ \\
\hline
\end{tabular}

${ }^{\mathrm{a}} \mathrm{O}=$ väkirehuna litistetty ohra; $\mathrm{OR}=$ väkirehuna litistetty ohra + rypsi; TR = väkirehuna teollinen täysrehu.

${ }^{\mathrm{b}}$ Keskiarvon keskivirhe.

${ }^{\mathrm{c}} \mathrm{R}=$ Ruokintakäsittely, $\mathrm{K}=\mathrm{Koe}, \mathrm{R} \times \mathrm{K}=$ Ruokintakäsittelyn ja kokeen yhdysvaikutus. Ruokintojen väliset erot testattiin ortogonaalisilla kontrasteilla: $\mathrm{C} 1=\mathrm{O}$ vs. OR ja $\mathrm{C} 2$

$=\mathrm{O}$ vs. TR. $* * *(\mathrm{p}<0,001), * *(\mathrm{p}<0,01), *(\mathrm{p}<0,05)$ ja o $(\mathrm{p}<0,10)$.

${ }^{\mathrm{d}}$ Lihakkuus: $(1=$ heikoin, $15=$ paras $)$.

e Rasvaisuus: ( 1 = rasvaton , $5=$ erittäin rasvainen). 


\section{Kasvu- ja teurastulokset}

Taulukossa 4 on esitetty sonnien elopainon kehittyminen kokeen alusta kokeen loppuun. Kokeen alussa ennen eri ruokinnoille siirtymistä ohraryhmän vasikat olivat kaikista pienimpiä, juottokauden lopussa eri ryhmien keskimääräiset painot eivät eronneet toisistaan. Puolen vuoden iässä OR-seosta ja täysrehua saaneiden sonnien painot eivät eronneet ( $241 \mathrm{vs.} 242 \mathrm{~kg}$ ), mutta O-ruokinnalla olleet olivat 26 kg kevyempiä. Ero kuitenkin tasoittui loppukasvatuksen myötä, eikä merkitsevää eroa kokeen lopussa enää ollut.

Päiväkasvut erosivat pelkästään teinikasvatuskauden (2,5 kk-6kk) aikana (Taulukko 4), jolloin OR-ruokinnalla päiväkasvut olivat $157 \mathrm{~g}$ ja TR-ruokinnalla $186 \mathrm{~g}$ enemmän kuin O-ruokinnalla. Loppukasvatuksen aikana päiväkasvuissa ei ollut eroja. Koko kokeen aikaisissa päiväkasvuissa ei ollut merkitseviä eroja, sillä kaikkien ryhmien keskimääräiset päiväkasvut poikkesivat vain muutamia kymmeniä grammoja toisistaan. Lisävalkuainen ei parantanut kasvutuloksia koko kasvatuskautta tarkastellessa, kuten ei aiemmissakaan kotimaisissa kokeissa (Huuskonen ym. 2007, 2008, Huuskonen ym. 2009, Manninen ym. 2011). Eri ruokinnoilla olleet eläimet eivät eronneet teurastuloksiltaan toisistaan (Taulukko 4). Lihakkuudeltaan sonnit olivat kohtalaista $\mathrm{O}$ - tasoa ja rasvaisuudelta keskirasvaisia.

\section{Yhteenveto ja johtopäätökset}

Lisävalkuainen paransi päiväkasvuja alkukasvatuskaudella. Tämä saatu ero kuitenkin menetettiin loppukasvatuskaudella eikä teuraspainoissa ollut merkitsevää eroa ruokintojen välillä. Lisävalkuaisruokinnasta ei koko kasvatuskautta ajatellen ole etua naudanlihantuotannossa, jos sonnit kasvatetaan välitysvasikoista teurasikään samalla tilalla. Valkuaislisän alkukasvatuskaudella saatu lisäkasvu kompensoituu loppukasvatuskauden aikana eikä valkuaislisään sijoitettu panos tuota taloudellista etua ruokittaessa sonneja hyvälaatuisella säilörehulla. Suomessa osa maitorotuisista lihasonneista kasvatetaan kuitenkin kolmivaihekasvatuksena, jolloin eläimet ovat välikasvattamoissa 4-6 kuukauden ikään saakka kunnes ne siirretään loppukasvattamoon kasvamaan teuraskypsiksi. Nuoret välitettävät sonnit hinnoitellaan painon mukaan. Tällaisessa tilanteessa välikasvattajan kannattaisi ruokkia nuoria vasikoita lisävalkuaisella, koska näin ruokitut eläimet ovat painavampia kuin pelkällä ohralla ruokitut eläimet ja näin ollen välikasvattajan olisi mahdollista saada taloudellista etua suuremmilla sonneilla. Taloudellinen voitto riippuu kuitenkin pitkälle rypsin ja ohran hinnasta sekä myös sonnin hinnoitteluperusteista.

Täysrehulla ei saavutettu etuja viljaväkirehuun nähden. Täysrehun ohraa korkeampi valkuaispitoisuus paransi kasvuja alkukasvatuskaudella samoin kuin pelkkä rypsilisä, mutta tämä ero kompensoitui loppukasvatuskauden aikana. Sonnit myös söivät täysrehua enemmän kuin ohraa, koska se sisälsi huonommin sulavia komponentteja. Näin ollen rehukustannukset ovat myös tässä suhteessa korkeammat. Näin ollen täysrehun käyttäminen teurassonnien kasvatuksessa ei ole taloudellisesti katsottuna järkevää, koska sillä ei myöskään saada lisähyötyä esimerkiksi ruhon laadussa.

\section{Kirjallisuus}

Huhtanen, P., Näsi, M. \& Khalili, H. 1989. By-products from integrated starch-ethanol production from barley in the diets of growing cattle. J. Agric. Sci. Finl. 61: 451-462.

Huuskonen, A. 2009a. The effect of cereal type (barley versus oats) and rapeseed meal supplementation on the performance of growing and finishing dairy bulls offered grass silage-based diet. Livest. Sci. 122: 53-62.

Huuskonen, A. 2011. Effects of barley grain compared to commercial concentrate or rapeseed meal supplementation on performance of growing dairy bulls offered grass silage-based diet. Agric. Food Sci. 20: 191-205.

Huuskonen, A., Khalili, H. \& Joki-Tokola, E. 2007. Effects of three different concentrate proportions and rapeseed meal supplement to grass silage on animal performance of dairy-breed bulls with TMR feeding. Livest. Sci. 110:154-165.

Huuskonen, A., Khalili, H. \& Joki-Tokola, E. 2008. Need for protein supplementation in the diet of growing bulls fed total mixed ration based on moderate digestible grass silage and barley. Agric. Food Sci. 17: 109-120

Minson, D.J. 1982. Effect of chemical composition on feed digestibility and metabolizable energy. Nutr. Abstr. Rev. 52: 591-615.

Manninen, M., Honkavaara, M., Jauhiainen, L., Nykänen, A. \& Heikkilä, A-M. 2011. Effects of grass-red clover silage digestibility and concentrate protein concentration on performance, carcass value, eating quality, and economy of finishing Hereford-bulls reared in cold conditions. Agric. Food Sci. 20: 151-168.

MTT 2010. Rehutaulukot ja ruokintasuositukset. Maa- ja elintarviketalouden tutkimuskeskus. Verkkojulkaisu. Saatavissa internetistä: https://portal.mtt.fi/portal/page/portal/Rehutaulukot. Viitattu 1.11.2011 